Article

\title{
Comparison of Laboratory and Computational Models of Selected Thermal-Technical Properties of Constructions Systems Based on Wood
}

\author{
Jozef Švajlenka ${ }^{1, * \mathbb{C}}$, Mária Kozlovská ${ }^{2}$, František Vranay ${ }^{3}$, Terézia Pošiváková ${ }^{4}$ and \\ Miroslava Jámborová ${ }^{5}$ \\ 1 Laboratory of Construction Technology and Management, Department of Construction Technology, \\ Economy and Management, Faculty of Civil Engineering, Technical University of Košice, \\ 04200 Košice, Slovakia \\ 2 Department of Construction Technology, Economy and Management, Faculty of Civil Engineering, \\ Technical University of Košice, 042000 Košice, Slovakia; maria.kozlovska@tuke.sk \\ 3 Laboratory of Building Construction, Department of Building Construction, Faculty of Civil Engineering, \\ Technical University of Košice, 042000 Košice, Slovakia; frantisek.vranay@tuke.sk \\ 4 Department of the Environment, Veterinary Legislation and Economy, University of Veterinary Medicine \\ and Pharmacy in Košice, 04181 Košice, Slovakia; terezia.posivakova@uvlf.sk \\ 5 Department of Process and Environmental Engineering, Faculty of Mechanical Engineering, Institute of \\ Power and Process Engineering, Technical University of Košice, 04200 Košice, Slovakia; \\ miroslava.jamborova@tuke.sk \\ * Correspondence: ingsvajl@gmail.com
}

Received: 5 May 2020; Accepted: 11 June 2020; Published: 16 June 2020

check for updates

\begin{abstract}
Energy-efficient buildings, sustainable buildings, smart buildings, nearly zero-energy buildings, passive and active buildings are construction concepts widely recognised as setting the latest trends. The purpose of their design is to create an optimal thermal microclimate by means of heat flows that are either formed within it or enter into it. This research paper presents an analysis of the measurements of the density of heat flows, their spread in building constructions, all of which is examined in laboratory conditions and confronted with calculation models. The hypothesis of this research is to confirm or refute whether the computational models match the laboratory simulations in terms of thermal-technical parameters. The research uses a methodology designed for examining building constructions under virtually stable conditions. Two variants of external sandwich walls based on prefab cross laminated timber panels (variant A) and structural insulated panel (variant B) were proposed as the subject of the study. Both variants were subjected to research in laboratory conditions and computational simulations. For the sake of comparison, the calculation simulations that manufacturers of wood construction systems typically declare were also performed. The results of the analyses show significant differences between the theoretical or declared parameters and the values measured in laboratory conditions (7.5-32.6\%). The deviations of the experimental measurements from the calculated or declared parameters were not as significant for variant $A$ as they were for variant $B$. These findings show that for these analysed sandwich structures based on wood, it is not always possible to reliably declare calculated values of thermal-technical parameters. The publication is also a contribution to the current needs in the field of heating technology in terms of sustainability and the quality of internal environments.
\end{abstract}

Keywords: cross laminated timber; CLT; energy; prefab construction; structural insulated panel; SIPS; thermal; wood 


\section{Introduction}

Modern methods of construction based on wood are highly diverse and can be individually customised and combined [1]. Modern residential wood constructions can be divided, according to the character of their vertical supporting structure, into solid-wood constructions, skeletal constructions and elemental constructions built from individual elements [2]. The individual categories differ from each other significantly in terms of their construction method, appearance and the manufacturing possibilities of the structural elements [3]. The most common solid-wood constructions are log constructions, which are still built today, although this category has now been expanded to include modern solid-wood constructions [4]. The categories of skeletal and elemental constructions are developed from half-timbered constructions and represent a construction method using wattle [5]. In addition to traditional wood construction methods, there are also hybrid methods developed in recent years, which combine wood as a construction material with other construction materials [6].

Hybrid constructions include systems from layered solid wood and constructions from skeletal structures [7]. Solid wood structures usually take the form of large-size sheet elements. Depending on the manufacturer or the product, solid wood structures can be single-layered or multi-layered-in the latter type the multiple layers are either glued together or joined with pins or nails [8]. Construction elements joined with pins do not require an adhesive and use the effect of lower moisture content. Wooden pins with a moisture content of $6 \%$ are inserted into drilled holes with a moisture content of $12 \%$. The moisture content in the pins and the moisture content in the structure will soon equalise, causing the inserted pins to expand, which ensures a firm joining. Other systems use pressure-inserted aluminium pins. The layers are typically glued together with PVAc (polyvinyl acetate) adhesives or PUR (polyurethane) adhesives [9].

The interior side of sheet elements from solid wood can be lined, left as a finished interior surface, or fitted with a slatted frame to house the building's utility connections. As is the case with any external wall composition, it is necessary to align the diffusion resistance of the interior layers with the diffusion resistance of the exterior layers [10]. The advantage of leaving the interior solid wood surface as a finished interior surface is that it can bind excessive interior air moisture and release it again, helping to create the optimal humidity of the interior. External wall layers do not normally require plastic layers with diffusion resistance. Cross laminated timber systems are air-tight by their very nature [11]. Other systems, such as skeletal structures or structures with layers joined with pins, usually require the installation of additional layers by lining the walls with boards based on wood (e.g., oriented strand board, OSB) or other air-tight layers to prevent air ingress [8].

Coniferous wood is used as the material (spruce wood, fir wood). Alternatively, certain less-common materials (particle boards, OSB boards) are also used [12]. Wall elements are manufactured with CNC-milled (computer numerical control-CNC) holes and grooves for utility connections [13]. Ceilings and roof elements can either be manufactured in the same way as wall elements, or wall elements are combined with other structures. The degree of prefabrication or readiness for assembly can vary. Individual sheet elements are assembled in the superstructure at the construction site according to the assembly procedure of the specific manufacturer.

It is mainly prefab products and products from solid wood, which include cross laminated wood products [14], that make a modern wood construction an interesting and sustainable construction technology [15]. Statistical data on the market share of wood constructions show that the construction of wood buildings is becoming increasingly important [16]. The methods of manufacturing and building wood constructions vary [17]. At the beginning of the planning process, the primary concern for the investor is the choice of a construction technology and materials for its construction [18]. When making this investment decision, it is not sufficient to consider economic criteria such as construction, operation and maintenance costs, or the cost of financing [19]. The success of a construction is also determined by construction-physical, technical and ecological criteria [20].

Cross laminated timber (CLT) panels are a construction material with properties suitable for modern wood constructions, made from layers of solid wood oriented perpendicular to adjacent layers 
and glued together. This reduces deformations in the wood to a negligible level [14]. The material makes it easy to build virtually all types of residential and non-residential buildings. CLT constructions are eco-friendly, precise, dimensionally stable, air-tight and diffusely open, but can also be diffusely closed [21]. They have excellent statics-related properties. The construction system is very simple and easy to manufacture, with a minimal number of layers. Owing to their properties, CLT panels offer virtually unlimited possibilities in construction and architecture [22]. They can be combined with other construction materials without complications. They are also a suitable construction element for passive houses. They are primarily used as internal and external walls, ceilings and roofs in new family houses and apartment buildings. They are suitable for reconstructions, extensions and indoor constructions [23]. CLT panels form the supporting structure of a construction, whose external side requires thermal insulation. All common thermal insulation materials are suitable for insulating CLT panels, including polystyrene, mineral wool and other environmentally more suitable alternatives, for example those based on wood fibre or other natural materials.

Structural insulated panels (SIPS) technology was invented in the United States. It is a sandwich panel consisting usually of two OSB boards, which is filled with expanded polystyrene as an insulating core serving as a sound and thermal insulator. It is a building system that is used to make low-energy and passive buildings [24]. At present, this system has developed to such an extent that it can compete with frame structures and prefabricated timber structures, as it exhibits good thermal insulation properties, high strength and minimal material costs in relation to those available in the market. The panels are used in the construction of perimeter walls, partitions, ceilings and roofs when the thickness of the insulation determines the required thermal insulation properties. SIPS panels can be manufactured as large-area elements with prepared openings for windows and doors. These large-area elements are transported to the construction site by special semi-trailers and handled by crane. The advantage of this system is the quick assembly of the house on the construction site [25]. The disadvantage of large-area panels is the more complex production technology, storage, transport and handling of parts in production and on the construction site [26]. Another problem can occur if the base plate does not meet the prescribed dimensions or if the investor requests additional changes to the project.

Wood constructions are well-suited to provide excellent thermal comfort for users even with wooden walls [27] that are relatively thin compared to masonry constructions [28]. This is due to the use of highly efficient thermal insulation in all layers of wood structures (external walls and ceilings). As there is a great deal of prejudice regarding the quality of the internal environment in such constructions due to their low accumulation capacity of thermal energy, and regarding the build quality and the quality of the materials used, it is necessary to perform analyses and measurements on actual structural parts of constructions based on wood that use wood as the supporting construction material [29].

A reduction in energy demand in buildings is usually achieved by improving the thermal insulation properties of building structures [30], through a more efficient design, and by choosing materials that are efficient in terms of thermal insulation parameters. It is necessary for building designs to rely on theoretical knowledge that accommodates energy efficiency [31] and the environmental principles of creating the optimal state of the internal environment of buildings that allow achieving more sustainable buildings [32,33]. For a solution for a specific thermal state of the environment that meets the expectations [34] and requirements of the given user, it is necessary to analyse the relations between the parameters of the thermal state of the environment [35] and energy demand for heating [36]. In an effort to analyse the problem of the range of the actual parameters of air temperature, it is important to consider their connection with the thermal insulation properties of external structures and thus with energy demand [37]. It is widely accepted that energy demand for heating decreases with improved thermal-technical properties of external structures [38]. In analysing thermal comfort parameters, attention is focused on the effect of the average coefficient of thermal transmittance as a coefficient acting in the monitored interaction, on energy demand and on the anticipated range of temperatures with the most frequent occurrence [39]. The economic consequences in terms of efficient 
use of energy as well as financial resources are undoubtedly also a very important part of sustainable solutions as such [40].

This research was a response to the need to verify the actual values of selected thermal-technical parameters of construction solutions based on wood by confronting them with the calculated or declared values stated by manufacturers and providers of construction systems based on prefab cross laminated timber panels and structural insulated panels. The hypothesis of this research was to confirm or refute whether the computational models match the laboratory simulations in terms of thermal-technical parameters.

\section{Materials and Methods}

Two variants of the structural parts of external walls using prefab cross laminated timber panels and structural insulated panels were proposed as the subject of the study. The examined variants were analysed in laboratory conditions in simulations of the surrounding environment and in a theoretical study of selected thermal-technical. The individual methodologies are presented in the following sub-chapters.

\subsection{Characterisation of the Examined Design Variants}

The examined structures or the examined solution variants were proposed so as to reflect the construction solutions used in actual construction practice. Both investigated variants were designed to be comparable in terms of energy standard.

The difference between the compared variants lay mainly in the material basis of thermal insulation and the main structural panel. In the first variant, the thermal insulation consisted of the commonly used thermal insulation system based on EPS polystyrene and CLT prefab panel. The second variant used thermal insulation based on EPS polystyrene and SIPS prefab panel. The size of the examined samples was $2.5 \mathrm{~m} \times 2 \mathrm{~m}$, with the corresponding material compositions of the compared variants. The detailed composition of the examined variants is presented in Tables 1 and 2.

Table 1. Structure of layers from the interior to the exterior-variant A.

\begin{tabular}{|c|c|c|c|c|c|}
\hline Layer Name & $\begin{array}{l}\text { Mass Density } \\
\rho\left(\mathrm{kg} / \mathrm{m}^{3}\right)\end{array}$ & $\begin{array}{c}\text { Layer } \\
\text { Thickness } \\
\text { d (mm) }\end{array}$ & $\begin{array}{c}\text { Thermal } \\
\text { Resistance } \\
\mathbf{R}_{\mathrm{d}}\left(\mathrm{m}^{2} . \mathrm{K} / \mathrm{W}\right)\end{array}$ & $\begin{array}{c}\text { Thermal Conductivity } \\
\text { Coefficient } \\
\lambda_{d}(W /(. m . K))\end{array}$ & $\begin{array}{l}\text { Diffusion } \\
\text { Resistance } \\
\text { Factor } \mu(-)\end{array}$ \\
\hline Cross laminated timber & 470 & 100 & 0.909 & 0.11 & $40-70$ \\
\hline $\begin{array}{l}\text { PUR adhesive for thermal } \\
\text { insulation boards }\end{array}$ & $15-25$ & - & - & 0.035 & 28 \\
\hline Thermal insulation-EPS & $13.5-18$ & 200 & 5.128 & 0.038 & $20-40$ \\
\hline Construction adhesive & 1400 & 2.5 & 0.005 & 0.45 & 25 \\
\hline Plastering & 1200 & 2.5 & 0.005 & 0.5 & 25 \\
\hline
\end{tabular}

\subsection{Method of Measuring Heat Flows in Determining the Thermal Transmittance Coefficient}

This chapter presents the procedure for measuring the actual value of the thermal transmittance coefficient in building constructions (U) in laboratory conditions. A non-destructive method of measuring a heat flow is used, from which the $U$ value is calculated.

For the determination of selected thermal-technical parameters of building materials, each country has its own standard recommendations, which are in most countries of the European Union taken from European standards. For laboratory as well as computational simulations, standards were taken into account as a basis, which provide the most accurate springboard for valid examination and derivation of valid conclusions. The works of Buday [41] and Jochim [42] followed a similar approach. The mentioned works, similarly to this presented research work, examined the properties of building materials and structural parts of wood-based buildings on the basis of simulations. 
Table 2. Structure of layers from the interior to the exterior-variant B.

\begin{tabular}{|c|c|c|c|c|c|}
\hline Layer Name & $\begin{array}{l}\text { Mass Density } \\
\rho\left(\mathrm{kg} / \mathrm{m}^{3}\right)\end{array}$ & $\begin{array}{c}\text { Layer } \\
\text { Thickness } \\
\text { d (mm) }\end{array}$ & $\begin{array}{c}\text { Thermal } \\
\text { Resistance } \\
\mathbf{R}_{\mathrm{d}}\left(\mathrm{m}^{2} \cdot \mathrm{K} / \mathrm{W}\right)\end{array}$ & $\begin{array}{c}\text { Thermal Conductivity } \\
\text { Coefficient } \\
\lambda_{d}(W /(. m . K)) \\
\end{array}$ & $\begin{array}{l}\text { Diffusion } \\
\text { Resistance } \\
\text { Factor } \mu(-)\end{array}$ \\
\hline Drywall & 750 & 12.5 & 0.057 & 0.15 & 9 \\
\hline OSB boards & 650 & 15 & 0.107 & 0.13 & 50 \\
\hline Thermal insulation—EPS & $13.5-18$ & 140 & 3.59 & 0.038 & $20-40$ \\
\hline OSB boards & 650 & 15 & 0.107 & 0.13 & 50 \\
\hline $\begin{array}{l}\text { PUR adhesive for thermal } \\
\text { insulation boards }\end{array}$ & $15-25$ & - & - & 0.035 & 28 \\
\hline Thermal insulation-EPS & $13.5-18$ & 100 & 2.564 & 0.038 & $20-40$ \\
\hline Construction adhesive & 1400 & 2.5 & 0.005 & 0.45 & 25 \\
\hline Plastering & 1200 & 2.5 & 0.005 & 0.5 & 25 \\
\hline
\end{tabular}

The examination of the design variants used a method of measuring the density of a heat flow passing through the structure (sample) and of measuring surface temperatures in stabilised thermal conditions, i.e., under virtually stable conditions. The data obtained from the experimental measurements in laboratory conditions were added to Formula (1) according to the STN 730540 standard [43].

$$
U=\frac{q}{\left(\theta_{\mathrm{ai}}-\theta_{\mathrm{ae}}\right)}\left(\mathrm{W} / \mathrm{m}^{2} \mathrm{~K}\right)
$$

where:

$q$-heat flow density $\left(\mathrm{W} / \mathrm{m}^{2}\right)$

$\theta_{\mathrm{ai}}-\theta_{\mathrm{ae}}$ - difference between the temperatures on the internal and external surface of the structure $\left[{ }^{\circ} \mathrm{C}\right]$.

The following material-technical equipment was used when applying the above method of determining the $U$ value from the measured heat flow density: the ALMEMO 5690-2 (Ahlborn) measuring centre, surface temperature sensors, a plate for measuring heat flows and temperature and ambient humidity sensors (Figure 1). The examined design variants were placed in a climate chamber, where stable ambient conditions were simulated. The simulated temperatures were exterior and interior temperatures ranging from $-13{ }^{\circ} \mathrm{C}$ to $20^{\circ} \mathrm{C}$ [44]. The examined samples placed in the climate chamber THERMOTRON.

The analysed constructions were designed to meet the minimum dimensions for examination under laboratory conditions according to the standards mentioned above. The samples analysed by us were even larger than the recommended standard for such types of measurements. According to logical and standard recommendations, the arrangement of the measuring sensors was in the middle of the samples so that the so-called influence of the measuring points by the edge cooling of the samples did not occur. Thus, this main requirement has been met. Sensors for measuring surface temperatures are attached to the structure and secured against tearing and also covered so that they are not affected by the air flow in the climate chamber. The plate for measuring the heat flow was placed on the interior side of the structure by gluing so as to ensure the best possible touch from the structure. The locations of the individual measuring points collided with the data that were needed to fit into the appropriate formulas for the calculation of thermal technical parameters measured in the laboratory conditions. 


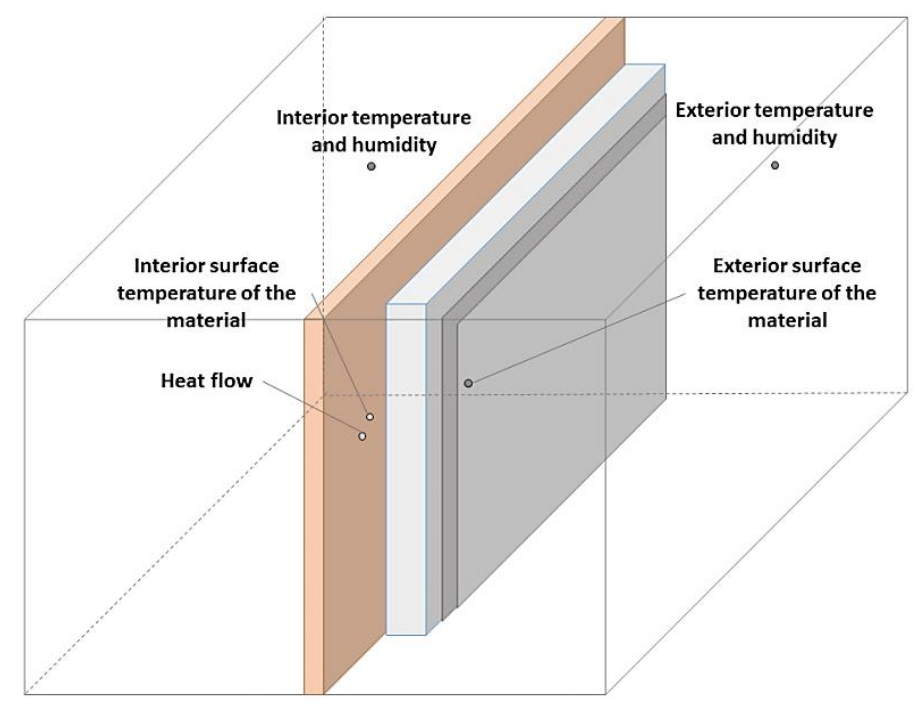

(a)

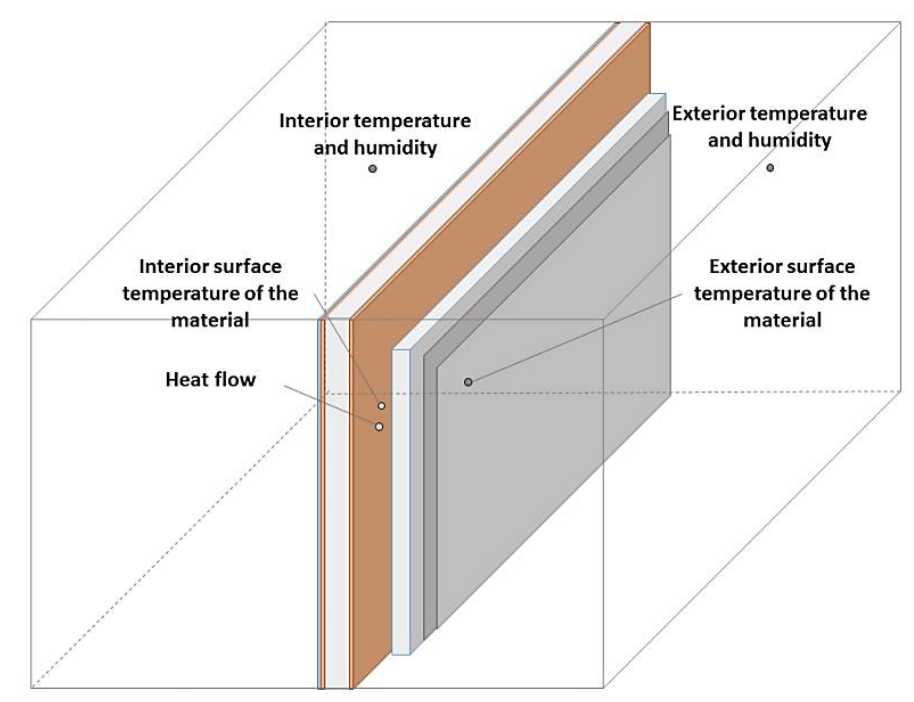

(b)

Figure 1. Test samples under laboratory conditions and location of measuring points. Note: (a) Prefab cross laminated timber structure, locations of measuring points-variant A; (b) prefab structural insulated panels, locations of measuring points-variant B. (Note: the compositions of the layers of individual structures are given in Tables 1 and 2).

\subsection{Calculation Method of Determining the Thermal Transmittance Coefficient}

For the purpose of confronting the experimental measurements of the thermal transmittance coefficient in laboratory conditions, the thermal transmittance coefficient value for the examined structures was also verified using a theoretical calculation according to the STN 730540 standard [43]. The theoretical calculation value was determined based on Formula (2). This calculation value is normally stated as the value declared by manufacturers and dealers of the individual construction systems.

$$
U=\frac{1}{\left(R_{i}+R+R_{e}\right)}\left(\mathrm{W} / \mathrm{m}^{2} \mathrm{~K}\right)
$$

where: 
$R i$-resistance for the thermal transmittance on the interior side $\left[\mathrm{m}^{2} \mathrm{~K} / \mathrm{W}\right]$

$R e$-resistance for the thermal transmittance on the exterior side $\left(\mathrm{m}^{2} \mathrm{~K} / \mathrm{W}\right)$

$R$-thermal resistance of the construction $\left(\mathrm{m}^{2} \mathrm{~K} / \mathrm{W}\right)$.

Comparable limit ambient conditions for both variants were used for calculating thermal-technical properties. The limit conditions for calculating $U$ for thermal transmittance were chosen as follows: Rsi $=0.13\left(\mathrm{~m}^{2} \cdot \mathrm{K}\right) / \mathrm{W}$ a Rse $=0.04\left(\mathrm{~m}^{2} \cdot \mathrm{K}\right) / \mathrm{W}$, internal and external temperature $\theta_{\mathrm{i}}=20.00{ }^{\circ} \mathrm{C} \mathrm{a}$ $\theta_{\mathrm{e}}=-12.00{ }^{\circ} \mathrm{C}$, relative internal and external air humidity $\theta_{\mathrm{i}}=50.00 \%$ a $\theta_{\mathrm{e}}=84 \%$. The choice of boundary conditions was in accordance with the valid standards for our country so that these values conflict with the simulated laboratory boundary conditions. From this point of view, comparable boundary conditions were maintained so that the conclusions were as gentle as possible.

\section{Results and Discussion}

The simulation of laboratory limit conditions was performed for a period of $24 \mathrm{~h}$, as the monitoring showed that this period was sufficient for the thermal condition of the sample to stabilise. The development of the measured parameters during the simulations for both variants are shown in Figures 2 and 3. Figures 2 and 3 show the essential parameter heat flow through which various thermal parameters can be derived. In this case, we were mainly interested in the heat flux through the structure and the surface temperatures of the material we examined. By means of the mentioned parameters, it is possible to evaluate the construction in terms of selected thermal technical parameters and compare them with the calculation model. Through experimental simulations and computational models, we verified the established hypothesis.

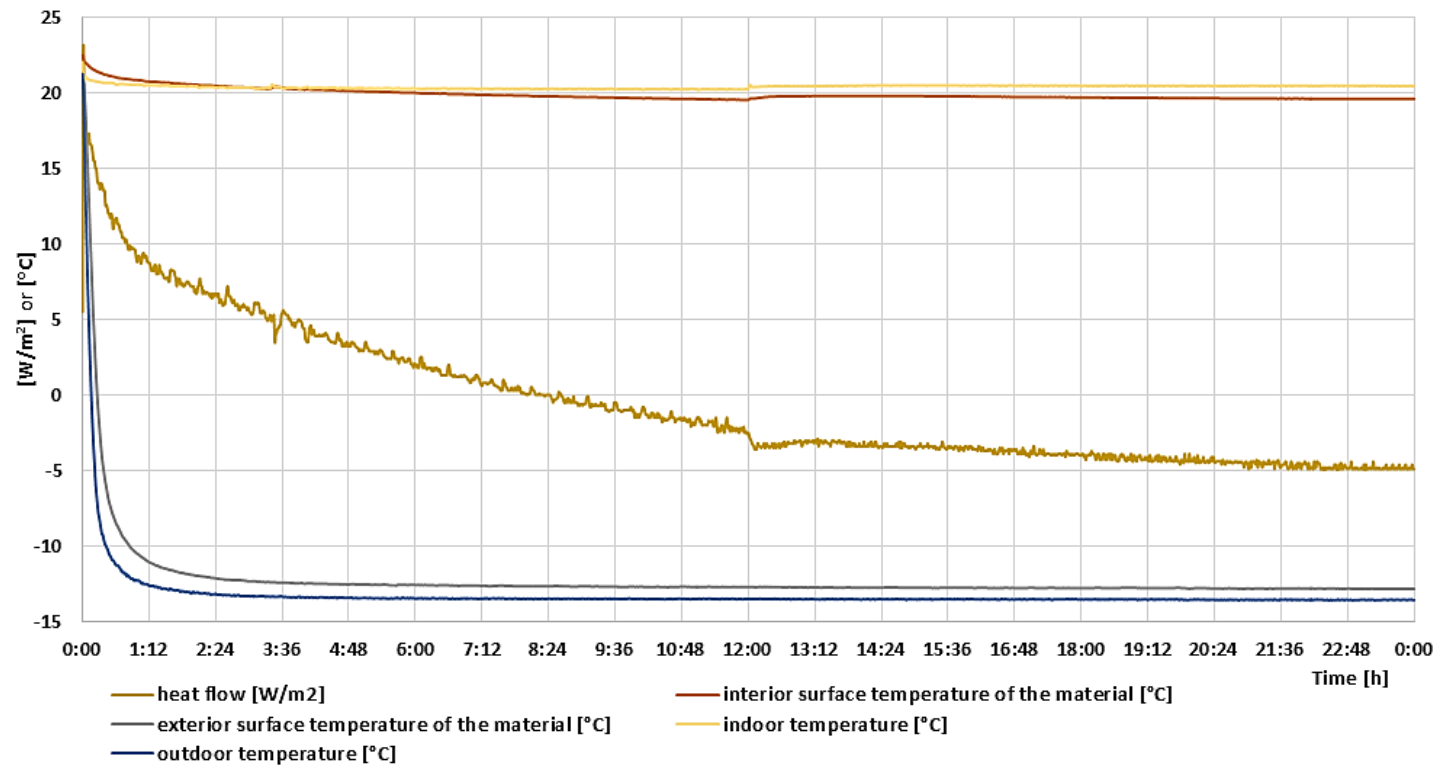

Figure 2. Development of the measured parameters during simulations-variant A.

In Figures 2 and 3, it is possible to observe a certain jump at about $12 \mathrm{~h}$, which was caused by the fact that at this point the chamber was stopped for a short time and thermal imaging images of the structure were taken. This imaging lasted only a moment and then the simulation continued. Thermal images were taken to verify the correctness of the location of the measuring points. 


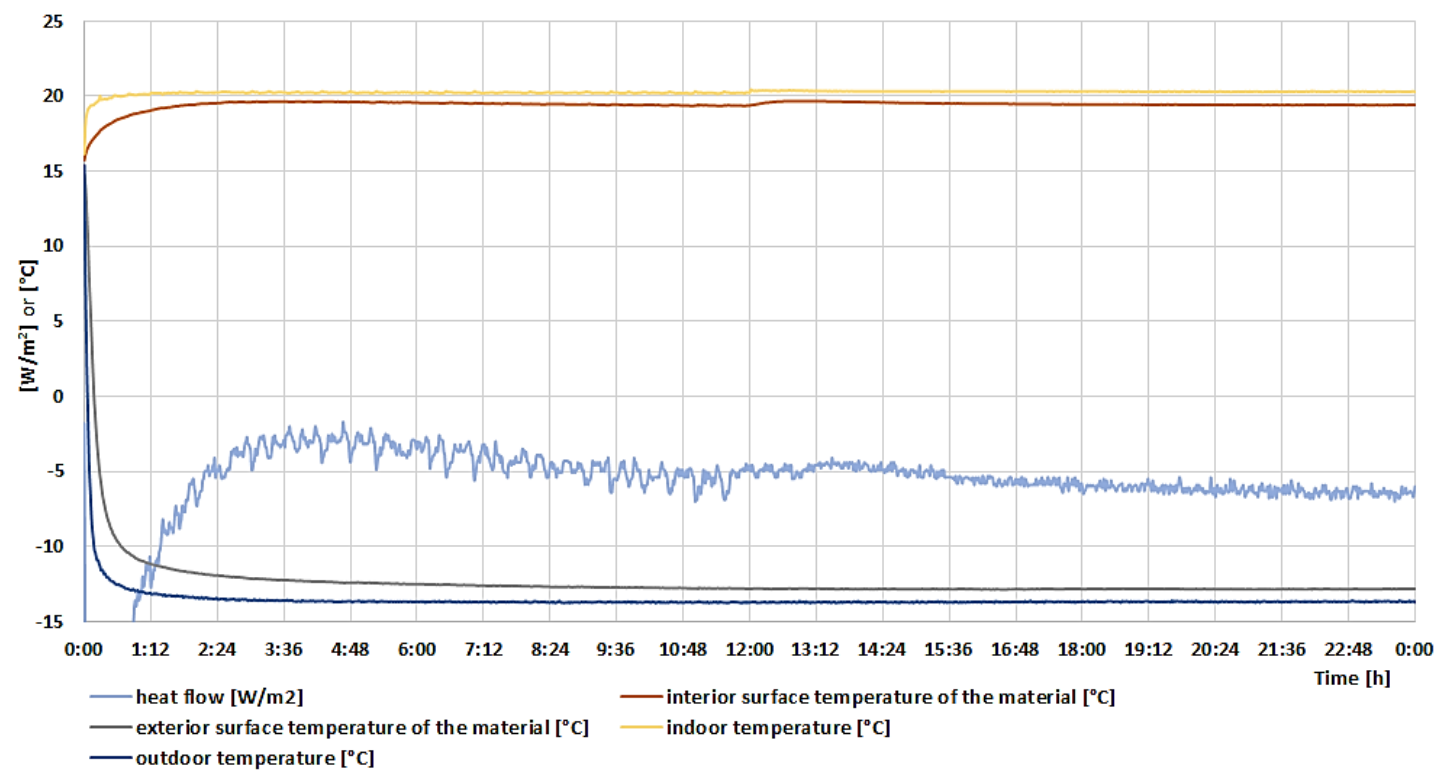

Figure 3. Development of the measured parameters during simulations-variant B.

Description of the measured values of $U$ after stabilisation of the temperature state of the sample are shown in Table 3. The average thermal transmittance coefficient values that were recorded in the experimental measurements in laboratory conditions were $0.148 \pm 0.005 \mathrm{~W} / \mathrm{m}^{2} \mathrm{~K}$ for variant $\mathrm{A}$ and $0.199 \pm 0.007 \mathrm{~W} / \mathrm{m}^{2} \mathrm{~K}$ (Table 3) for variant B. The difference between the compared variants was $25,62 \%$.

Table 3. Description of measured U values after the stabilisation of the thermal condition of the sample.

\begin{tabular}{ccc}
\hline & U Value $\left(\mathbf{W} / \mathbf{m}^{2} \mathbf{K}\right){ }^{*}$ & U Value $\left(\mathbf{W} / \mathbf{m}^{2} \mathbf{K}\right){ }^{*}$ \\
\hline Variant A & Variant B \\
\hline \pm std & 0.148 & 0.199 \\
\hline Min & 0.005 & 0.007 \\
\hline Max & 0.136 & 0.180 \\
\hline median & 0.157 & 0.217 \\
\hline 25th perc. & 0.151 & 0.198 \\
\hline 75th perc. & 0.148 & 0.195 \\
\hline \multicolumn{2}{r}{ Note: * the sample is temperature stable. }
\end{tabular}

For the purpose of confronting the experimental measurements of the thermal transmittance coefficient in laboratory conditions, the thermal transmittance coefficient value for the examined structures was also verified using a theoretical calculation. The theoretical calculation value was determined based on Formula (2). The $U$ value calculated for variant A was $0.16 \mathrm{~W} /\left(\mathrm{m}^{2} \cdot \mathrm{K}\right)$ and $\mathrm{U}$ $0.15 \mathrm{~W} /\left(\mathrm{m}^{2} \cdot \mathrm{K}\right)$ for variant $\mathrm{B}$. For variant $\mathrm{A}$, the final surface temperature $\Theta$ si of the structure was: $19.33{ }^{\circ} \mathrm{C}$, the thermal transmittance coefficient $\mathrm{U}$ was: $0.16 \mathrm{~W} /\left(\mathrm{m}^{2} \cdot \mathrm{K}\right)$, the diffusion resistance of the structure was: $0.23 \times 10^{9} \mathrm{~m} / \mathrm{s}$ and the thermal resistance $\mathrm{R}$ of the structure was: $6.043 \mathrm{~m}^{2} \cdot \mathrm{K} / \mathrm{W}$. For variant $B$, the final surface temperature $\Theta$ si of the structure was: $19.37^{\circ} \mathrm{C}$, the thermal transmittance coefficient $U$ was: $0.15 \mathrm{~W} /\left(\mathrm{m}^{2} \cdot \mathrm{K}\right)$, the diffusion resistance of the structure was: $0.23 \times 10^{9} \mathrm{~m} / \mathrm{s}$ and the thermal resistance $\mathrm{R}$ of the structure was: $6.431 \mathrm{~m}^{2} \cdot \mathrm{K} / \mathrm{W}$.

Certain differences were observed by comparing the theoretical measurement and the theoretical calculation of the thermal transmittance coefficient for both variants. For variant $A$, the difference between the measured and calculated value was $7.5 \%$. For variant $B$, the difference between the 
measured and calculated value was 32.6\%. These comparisons showed significant deviations from the calculated or declared values. It is also necessary to take into account certain limitations of the research and possible deviations caused by the measurements in laboratory conditions. However, the deviation of the measured values from the calculated ones was significantly greater for variant $B$ than for variant $\mathrm{A}$.

The comparison of the calculated thermal transmittance coefficient values for variant $A$ and variant B showed a difference of $6.25 \%$, which was not as significant as in the case of the comparison in laboratory conditions. The results reveal significant differences between the so-called theoretical or declared parameters and the values measured in laboratory conditions, which highlights the need to constantly check and verify the properties of design solutions.

The research limitations of this research are mainly in the accuracy of the measurement as the samples were examined under laboratory conditions. In laboratory measurements, it is necessary to take into account the inconsistency of the examined samples and the location of the measuring sensors. The measuring sensors may show some standard deviations in the measurement, which may ultimately skew the result. It is therefore important to carefully consider the laboratory technique used and the correct design of the measuring points and their location and attachment to the structure. As for the sample size, it was adapted to the size of the hole in the climatic chamber, but the sample size was larger than recommended by the standard for testing under such conditions. If the sample is smaller than recommended, data distortion could occur. In our case, this factor was minimised, so it did not happen. Another momentum is mathematical and computational models that need to be adapted to the boundary conditions that we simulated in the laboratory. Both in laboratory simulations and in computational simulations, it is necessary to set the boundary conditions so that they are comparable. It follows that if comparable boundary conditions are maintained, it is possible to eliminate inaccuracies and deviations of the resulting simulations.

\section{Discussion}

Cross laminated timber (CLT) is gaining in popularity. This construction system owes its popularity to its advantages, the most significant of which is its ratio of weight to static load capacity [45-47]. It is for this reason that this system is becoming the main competitor of traditionally used construction systems based on concrete, steel and masonry. Other advantages include the fact that the system allows a dry method of construction and the fact that constructions based on wood have favourable environmental parameters compared to traditional construction methods [14]. Wood constructions and construction systems based on wood behave differently to traditional solutions in certain situations in terms of the way they spread energy [48]. This is due to the fact that constructions based on wood are not homogeneous and are often built from so-called sandwich structural parts. Better understanding is needed of how individual design solutions behave in real conditions, which was also the aim of the presented research.

Many studies in the field of construction systems based on wood focus on verifying their fire safety properties [49-51]. This is crucial for understanding construction systems based on wood. Verification of thermal-technical parameters in terms of efficient use of energy during the use of constructions is also an important area where knowledge needs to be expanded, which was also the aim of the presented research. In the area of efficient spending of resources, mainly environmental interests are leaning, but economic aspects as such are becoming more and more popular at all levels. Within the mentioned area, it is possible to apply various sensory, intelligent technological solutions [52] through which it is possible to obtain the necessary data for decision-making processes [53] leading to an intelligent society, sustainable behaviour leading to economic growth [54].

Research by Chang et al. [55] focused on studying thermal bridges in the context of construction systems based on CLT. The authors state that CLT construction elements are becoming popular in Europe because of their low levels of carbon emissions compared to traditional construction material solutions. Other advantages the authors mention are short construction periods and favourable 
statics-related properties. The results of the analysis of the CLT construction system in the presented research confirm these claims. The experiment measurements performed by Chang et al. [55] showed that wood constructions based on CLT have smaller thermal bridges than wood constructions based on frame structures, which ultimately contributes to lower energy losses and more energy efficiency during the use of constructions based on CLT. These findings match the findings in the presented research from the laboratory measurements of selected thermal-technical properties of design variants based on CLT.

A special field of study related to prefab CLT panels is the study of hygrothermal performance [56,57]. From the point of view of the presented research, there are certain gaps and limitations in this field of study. Future research should focus on filling these gaps to expand the knowledge related to prefab CLT structures. Research by Wang and Ge [58] focused on studying the hygrothermal performance of cross laminated timber wall assemblies: a stochastic approach. The authors point out that certain configurations of sandwich structures with a prefab CLT panel as their supporting element allow the creation of a diffusely closed structure. On the other hand, the authors found that diffusely closed structures may lead to problems with hygrothermal performance. The study of the properties of prefab CLT panels in the presented research confirms these findings. However, it should be noted that it is difficult for many construction systems designed for wood constructions to achieve a diffusely closed state. Achieving a diffusely closed state may appear to be easy in the case of CLT constructions, but the reality may be different. This calls for a deeper understanding in the field, which is what we wish to focus on in our future work.

Research by Dong et al. [59] focused on energy consumption in buildings based on prefab CLT panels. The authors state that constructions based on prefab CLT panels may, in certain circumstances, become highly efficient in terms of their contribution to the energy balance of buildings where they are used as one of the structural components. These claims are in line with the presented research, where favourable values of the examined external walls based on prefab CLT panels were recorded. On the other hand, it must be pointed out that the laboratory analyses in the presented research showed significant deviations from the declared thermal-technical parameters. More in-depth knowledge is required in the study of the materials used in the structural parts of wood constructions based on CLT.

Research by Guo et al. [60] focused on the energy saving and carbon reduction performance of construction systems based on prefab CLT panels. The results of the research show that buildings based on prefab CLT panels perform better than buildings based on reinforced concrete particularly in terms of energy saving and carbon reduction. Although the presented research examined different parameters, we agree with these authors' conclusions, as construction systems based on wood are undoubtedly a more environmentally efficient solution compared to traditional solutions. Moreover, prefab CLT panels offer excellent statics-related properties. It should be noted, however, that it is not always desirable to prioritise construction solutions based on wood. The use of wood is still limited by certain properties compared to certain traditional solutions. It is therefore necessary to continue to expand the knowledge in the field of construction solutions based on wood.

In the field of construction, specifically in the field of construction solutions, on the one hand, it is important to design such construction solutions that are not only energy efficient but also environmentally acceptable. On the other hand, it is possible to reduce the negative balance of construction solutions in other ways, such as the use of alternative energy sources [61] needed for the operation of buildings as such. Because the conventional energy sources used so far for the operation of buildings are often not environmentally friendly and in terms of global environmental impacts are not a sustainable alternative with the desired effect for modern design and engineering solutions [62]. Therefore, it is necessary to consider this level in the design of future efficient buildings.

There are several studies in the field of the energy balance of constructions based on prefab CLT panels [63-65]. These studies considered certain theoretical characteristics or properties affecting the energy balance of constructions. Energy balance plays a major role in the efficient use of energy and financial resources for heating and cooling during the use constructions. The analyses in the presented 
research showed that certain thermal-technical parameters may differ from the declared or calculated ones. In evaluating various models, it is necessary to be cautious and to verify the considered material variants with experimental measurements. This will allow models where certain deviations from declared parameters are accommodated to reflect the reality more closely. In light of this, the presented research is beneficial in that it expands the knowledge in the field of constructions systems based on cross laminated timber.

The authors Adekunle and Nikolopoulou [66] dealt with thermal comfort in the summer in buildings based on prefabricated SIPS panels. The mentioned authors state that SIPS constructions are a comparable alternative to conventional constructions in terms of thermal comfort. However, this study points to certain disadvantages of SIPS prefabricated panels that are used in construction. The conclusion of this work shows that the structures that are heavier in volume than SIPS panels are more efficient. However, this work also states that under certain conditions, the SIPS panel can also be effective depending on the thermal insulation used. Similar findings were found in our research, where we found that construct A was more efficient than construct B.

Examination of the thermal-technical properties of SIPS panels was discussed by Wyss et al. [67]. In this study, they investigated the properties of SIPS prefabricated panels in a steady state similar to that of ours in our research. The conclusions of this research show that SIPS prefabricated panels are in accordance with the thermal-technical parameters of efficient construction. Because they provide significantly better thermal-technical parameters while maintaining a small thickness of the structure compared to conventional buildings and structures of construction. Our ideas agree with these views.

Investigation of the properties of building materials and structural parts of buildings requires realistic input data [68]. Constantly evolving construction systems, not only based on wood, require attention because of the extent to which they can compete with previously used construction solutions. The work of the author Vala [68] is similar to ours, it determines the thermal-technical properties, but in non-stationary conditions. Non-stationary conditions are closer to reality, as stationary conditions in real use of buildings only affect constructions inside the buildings. However, if it is necessary to verify the properties of the peripheral structures of buildings, non-stationary conditions are more reliable for evaluating the properties and behaviour of structural parts of buildings. The work of Zach et al. [69] also focused on the evaluation of selected thermal-technical properties of alternative building materials. A certain parallel in the ideas is, in particular, that the mentioned authors state, on the basis of their analyses, that not all the declared properties of the producers are the real ones. Based on our analyses, we confirm these facts. The authors Janczarek and Bulyandra [70] also dealt with this issue, who in their research compared real constructions with constructions in laboratory conditions. Based on their findings, it follows that with the right choice of boundary conditions that can be simulated in laboratory conditions, it is possible to obtain some valid data in comparison with the monitoring of the real structure. There are various computational models for the computational determination of thermal-technical properties of building materials [71]. However, in our work, in our research and analysis, we followed the standard recommendations for the most accurate findings. The other Albatici et al. [72] also dealt with other methods by which it is possible to verify the thermal-technical properties of building materials. The mentioned authors, like us, focused on the study of materials in laboratory conditions but through a different methodology.

In general, wood-based constructions are experiencing some progress in their popularity. However, many investors and the professional public have some doubts about their properties. Therefore, it is constantly necessary to expand knowledge in this cloud. In this presented work, we focused on the investigation and comparison of selected structural systems and their individual wall components in terms of selected thermal parameters. The key moment is the comparison of laboratory and computational and declared values, respectively. In this sense, the benefit of the research is mainly in terms of saturating the view of how the declared parameters differ from those measured in the laboratory conditions. The findings show that these values differ at certain moments and therefore it is necessary to take this into account in the future design of wood-based buildings. This work expands 
the knowledge in the study of thermal-technical properties of wood-based buildings. At present, there are many construction systems for the implementation of wood-based constructions. In addition, the individual construction systems are not the same if they are manufactured and implemented by other companies. Each manufacturer adapts the technology according to their needs and the needs of end consumers. Therefore, it is necessary to examine the various options that are currently being implemented. This work also contributes in this sense to the knowledge in the field of wooden buildings as such.

\section{Conclusions}

The problem of substance and temperature transfer in building constructions is significant particularly in terms of their energy consumption. Optimised material composition and architecture of wood constructions can achieve high levels of energy saving related to heating. Material research for modelling purposes was carried out with the aim to determine the material properties that are significant for thermal transmittance in structures. The thermal transmittance coefficient was determined using laboratory measurements of the examined variants. To confront the experimental measurements with the calculated parameters, the thermal transmittance coefficient was determined by calculation from basic material characteristics, while taking into account limit conditions comparable with the conditions simulated in laboratory conditions. The result of the experimental measurements was that variant $B$ exhibited better thermal transmittance values than variant $A$, which was also true of the calculated values. The results also showed significant differences between the theoretical or declared parameters and the parameters measured in laboratory conditions, particularly in the case of variant $B$. The deviations of the experimental measurements from the calculated or declared parameters were not as significant for variant $A$ as they were for variant $B$. These findings show that for these analysed sandwich structures based on wood, it is not always possible to reliably declare the calculated values of thermal-technical parameters.

Author Contributions: Conceptualization, Data curation, J.Š.; Formal analysis, J.Š., M.K., M.J.; Investigation, J.Š., T.P.; Methodology, J.Š.; Project administration, J.Š.; Resources, J.Š.; Software, J.Š.; Supervision, J.Š., M.K., F.V.; Validation, J.Š., M.K., T.P., M.J.; Visualization, J.Š., T.P.; Writing—original draft, J.S..; Writing—review \& editing, J.Š., T.P. All authors have read and agreed to the published version of the manuscript.

Acknowledgments: This publication is the result of the Project implementation: University Science Park TECHNICOM for Innovation Applications Supported by Knowledge Technology, ITMS: 26220220182,supported by the Research \& Development Operational Programme funded by the ERDF.

Conflicts of Interest: There are no conflicts of interest associated with this research.

\section{References}

1. Ramage, M.H.; Burridge, H.C.; Busse-Wicher, M.; Fereday, G.; Reynolds, T.P.S.; Shah, D.; Wu, G.; Yu, L.; Fleming, P.; Densley-Tingley, D.; et al. The wood from the trees: The use of timber in construction. Renew. Sustain. Energy Rev. 2017, 68, 333-359. [CrossRef]

2. Allen, E.; Iano, J. Fundamentals of Building Construction: Materials and Methods; John Wiley \& Sons: Hoboken, NJ, USA, 2019.

3. Vaverka, J. Wooden Buildings for Housing, 1st ed.; Grada: Praha, Czech Republic, 2008; p. 376, ISBN 978-80-247-2205-4.

4. Ho, T.; Dao, T.; Aaleti, S.; Van De Lindt, J.W.; Rammer, D. Hybrid system of unbonded post-tensioned CLT panels and light-frame wood shear walls. J. Struct. Eng. 2017, 143, 04016171. [CrossRef]

5. Bederka, M.; Makýš, P.; Duubek, M.; Petro, M. "Cement screeds-Selected methods of humidity measurement", Advances and Trends in Engineering Sciences and Technologies III. In Proceedings of the 3rd International Conference on Engineering Sciences and Technologies, ESaT 2018, Tatranské Matliare, Slovak, 12-14 September 2018; p. 299.

6. Gregorová, V.; Ďubek, M.; Ďubek, S.; Štefunková, Z. An experimental preparation of fibre concrete to software's detection of fibres. IOP Conf. Ser. Mater. Sci. Eng. 2019, 549, 012018. [CrossRef] 
7. Singh, T.; Page, D.; Simpson, I. Manufactured structural timber building materials and their durability. Constr. Build. Mater. 2019, 217, 84-92. [CrossRef]

8. Kobl, J. Wooden Buildings: Load-Bearing Structure Systems, Perimeter Cladding; Grada: Praha, Czech Republic, 2011; p. 320, ISBN 978-80-247-4071-3.

9. Veselý, V. Massive Wooden Buildings and Requirements for Them. 2013. Available online: https://stavba. tzbinfo.cz/vlastnostidrevostaveb/10345-masivni-drevostavby-a-pozadavky-na-ne-kladene (accessed on 10 February 2020).

10. Berglund, L.A.; Burgert, I. Bioinspired wood nanotechnology for functional materials. Adv. Mater. 2018, 30, 1704285. [CrossRef] [PubMed]

11. Quesada-Pineda, H.; Smith, R.; Berger, G. Drivers and Barriers of Cross-Laminated Timber (clt) Production and Commercialization: A Case of Study of Western Europe's clt Industry; BioProducts Business: Monona, WI, USA, 2018; pp. 29-38.

12. Woodard, A.C.; Milner, H.R. Sustainability of timber and wood in construction. In Sustainability of Construction Materials; Woodhead Publishing: Cambridge, UK, 2016; pp. 129-157.

13. Takabayashi, H.; Kado, K.; Hirasawa, G. Versatile Robotic Wood Processing Based on Analysis of Parts Processing of Japanese Traditional Wooden Buildings. In Robotic Fabrication in Architecture, Art and Design; Springer: Cham, Switzerland, September 2018; pp. 221-231.

14. Brandner, R.; Flatscher, G.; Ringhofer, A.; Schickhofer, G.; Thiel, A. Cross laminated timber (CLT): Overview and development. Eur. J. Wood Wood Prod. 2016, 74, 331-351. [CrossRef]

15. Flores, E.I.S.; Yanez, S.J.; Guzmán, C.F.; García-Macías, E.; Carlos, J. Multi-Scale Structural Mechanics for the Modelling of Cross-Laminated Timber Buildings; Universidad de Santiago de Chile: Santiago, Chile, 2018.

16. Matová, H.; Kaputa, V. Attitudes of active and upcoming architects towards wood: The case study in Slovakia. Acta Fac. Xylologiae 2018, 60, 199-210.

17. Hanak, T.; Korytarova, J. Procurement management in construction: Study of Czech municipalities. Open Eng. 2019, 9, 151-158. [CrossRef]

18. Gašparík, J.; Szalayová, S.; Alamro, B.; Gašparík, M. Optimization method of elevator selection for the realization of construction processes, Advances and Trends in Engineering Sciences and Technologies III. In Proceedings of the 3rd International Conference on Engineering Sciences and Technologies, ESaT 2018, Tatranské Matliare, Slovak, 12-14 September 2018; p. 369.

19. Isa, M.; Bakar, M.A.; Hasim, M.S.; Anuar, M.K.; Sipan, I.; Nor, M.Z.M. Data quality control for survey instrument of office investors in rationalising green office building investment in Kuala Lumpur by the application of Rasch analysis. Facilities 2017, 35, 638-657. [CrossRef]

20. Nirmul, D.; Scott, J. The New Resilient Built Environment: Perspectives from Investors and Owners of Private Buildings. In Optimizing Community Infrastructure; Butterworth-Heinemann: Oxford, UK, 2020; pp. 181-195.

21. Espinoza, O.; Trujillo, V.R.; Mallo, M.F.L.; Buehlmann, U. Cross-laminated timber: Status and research needs in Europe. BioResources 2015, 11, 281-295. [CrossRef]

22. Lukacs, I.; Björnfot, A.; Tomasi, R. Strength and stiffness of cross-laminated timber (CLT) shear walls: State-of-the-art of analytical approaches. Eng. Struct. 2019, 178, 136-147. [CrossRef]

23. Popovski, M.; Gavric, I. Performance of a 2-story CLT house subjected to lateral loads. J. Struct. Eng. 2016, 142, E4015006. [CrossRef]

24. Tejchman, J. Evaluation of strength, deformability and failure mode of composite structural insulated panels. Mater. Des. 2014, 54, 1068-1082.

25. Meng, Q.; Chen, W.; Hao, H. Vulnerability Analyses of Structural Insulated Panels with OSB Skins Strengthened by Basalt Fiber Cloth Subjected to Windborne Debris Impact. Int. J. Struct. Stab. Dyn. 2018, 18, 1850088. [CrossRef]

26. Murillo, M.; Tutikian, B.F.; Ortolan, V.; Oliveira, M.L.; Sampaio, C.H.; Gómez, L. Fire resistance performance of concrete-PVC panels with polyvinyl chloride (PVC) stay in place (SIP) formwork. J. Mater. Res. Technol. 2019, 8, 4094-4107.

27. Asdrubali, F.; Ferracuti, B.; Lombardi, L.; Guattari, C.; Evangelisti, L.; Grazieschi, G. A review of structural, thermo-physical, acoustical, and environmental properties of wooden materials for building applications. Build. Environ. 2017, 114, 307-332. [CrossRef] 
28. Motuzienè, V.; Rogoža, A.; Lapinskienè, V.; Vilutienė, T. Construction solutions for energy efficient single-family house based on its life cycle multi-criteria analysis: A case study. J. Clean. Prod. 2016, 112, 532-541. [CrossRef]

29. De Araujo, V.A.; Cortez-Barbosa, J.; Gava, M.; Garcia, J.N.; de Souza, A.J.D.; Savi, A.F.; Morales, E.A.M.; Molina, J.C.; Vasconcelos, J.S.; Christoforo, A.L.; et al. Classification of wooden housing building systems. BioResources 2016, 11, 7889-7901. [CrossRef]

30. Chwieduk, D.A. Towards modern options of energy conservation in buildings. Renew. Energy 2017, 101, 1194-1202. [CrossRef]

31. Hrdlicka, T.; Cupal, M. Brick versus wood construction in residential. In International Multidisciplinary Scientific GeoConference Surveying Geology and Mining Ecology Management; SGEM: Sofia, Bulgaria, 2019; p. 395.

32. Kaputa, V.; Olšiaková, M.; Mat'ová, H.; Drličková, E. Do preferences for wood-framed houses' attributes change over time? In Digitalisation and Circular Economy: Forestry and Forestry Based Industry Implications_-Proceedings of Scientific Papers; Union of Scientists of Bulgaria: Varna, Bulgaria, 2019; p. 161.

33. Králiková, R.; Andrejiová, M. Thermal comfort in the working environment-Assessment through objective and subjective approaches-2014. In Proceedings of the 5th ICEEE-2014 International Conference: Global Environmental Change and Population Health: Progress and Challenges, Budapest, Hungary, 19-21 November 2014; pp. 352-356.

34. Gou, S.; Nik, V.M.; Scartezzini, J.L.; Zhao, Q.; Li, Z. Passive design optimization of newly-built residential buildings in Shanghai for improving indoor thermal comfort while reducing building energy demand. Energy Build. 2018, 169, 484-506. [CrossRef]

35. Korytárová, J.; Hanák, T.; Kozik, R.; Radziszewska-Zielina, E. Exploring the contractors' qualification process in public works contracts. Procedia Eng. 2015, 123, 276-283. [CrossRef]

36. Zgútová, K.; Decký, M.; Šrámek, J.; Drevený, I. Using of alternative methods at earthworks quality control. Procedia Earth Planet. Sci. 2015, 15, 263-270. [CrossRef]

37. Wang, R.; Lu, S.; Feng, W. A three-stage optimization methodology for envelope design of passive house considering energy demand, thermal comfort and cost. Energy 2020, 192, 116723. [CrossRef]

38. Antošová, N.; Belániová, B.; Chamulová, B.; Janušová, K.; Takács, J. The protection of environment during cleaning ETICS with biocides, Advances and Trends in Engineering Sciences and Technologies III. In Proceedings of the 3rd International Conference on Engineering Sciences and Technologies, ESaT 2018, Tatranské Matliare, Slovak, 12-14 September 2018; p. 281.

39. Park, J.Y.; Nagy, Z. Comprehensive analysis of the relationship between thermal comfort and building control research-A data-driven literature review. Renew. Sustain. Energy Rev. 2018, 82, 2664-2679. [CrossRef]

40. Graessley, S.; Horak, J.; Kovacova, M.; Valaskova, K.; Poliak, M. Consumer attitudes and behaviors in the technology-driven sharing economy: Motivations for participating in collaborative consumption. J. Self-Gov. Manag. Econ. 2019, 7, 25-30.

41. Buday, P. The most significant factor affecting the calculation of specific heat consumption for heating for family houses according to STN 73 0540. Appl. Mech. Mater. 2016, 820, 171-176. [CrossRef]

42. Jochim, S. Determining the heat transfer coefficient of log-cabin walls based on one dimensional thermal transmittance. Acta Fac. Xylologiae Zvolen Publica Slovaca 2016, 58, 75.

43. STN 73 0540. Thermal Performance of Buildings and Components; Thermal Protection of Buildings, 2002. BUILD UP EU. Available online: https://www.buildup.eu/en/practices/publications/slovak-republic-stn-730540-3-2012-thermal-protection-buildings-thermal (accessed on 14 June 2020).

44. EN ISO 10456. Building Materials and Products—Hygrothermal Properties_Tabulated Design Values and Procedures for Determining Declared and Design Thermal Values; ISO: Geneva, Switzerland, 2007.

45. Stürzenbecher, R.; Hofstetter, K.; Eberhardsteiner, J. Structural design of Cross Laminated Timber (CLT) by advanced plate theories. Compos. Sci. Technol. 2010, 70, 1368-1379. [CrossRef]

46. Leijten, A.J. Europe goes green. Procedia Eng. 2017, 171, 104-112. [CrossRef]

47. Shahnewaz, M.; Tannert, T.; Alam, M.S.; Popovski, M. Capacity-Based Design for Platform-Framed Cross-Laminated Timber Buildings. In Proceedings of the Structures Congress 2017, Denver, CO, USA, 6-8 April 2017. 
48. Jing, L.; Hongpeng, X.; Xiabin, G.; Di, Y. Technical advantages and limitations of cross-laminated timber high-rise buildings. Urban. Archit. 2017, 14, 7.

49. Frangi, A.; Fontana, M.; Hugi, E.; Jübstl, R. Experimental analysis of cross-laminated timber panels in fire. Fire Saf. J. 2009, 44, 1078-1087. [CrossRef]

50. Schmid, J.; König, J.; Köhler, J. Fire-exposed cross-laminated timber-modelling and tests. In Proceedings of the World Conference on Timber Engineering, Trentino, Italy, 20-24 June 2010.

51. Klippel, M.; Schmid, J. Design of cross-laminated timber in fire. Struct. Eng. Int. 2017, 27, 224-230. [CrossRef]

52. Milward, R.; Popescu, G.H.; Michalikova, K.F.; Musova, Z.; Machova, V. Sensing, smart, and sustainable technologies in Industry 4.0: Cyber-physical networks, machine data capturing systems, and digitized mass production. Econ. Manag. Financ. Mark. 2019, 14, 37-43.

53. Kovacova, M.; Kliestik, T.; Pera, A.; Grecu, I.; Grecu, G. Big Data Governance of Automated Algorithmic Decision-Making Processes. Rev. Contemp. Philos. 2019, 18, 126-132.

54. Udell, M.; Stehel, V.; Kliestik, T.; Kliestikova, J.; Durana, P. Towards a smart automated society: Cognitive technologies, knowledge production, and economic growth. Econ. Manag. Financ. Mark. 2019, 14, 44-49.

55. Chang, S.J.; Wi, S.; Kim, S. Thermal bridging analysis of connections in cross-laminated timber buildings based on ISO 10211. Constr. Build. Mater. 2019, 213, 709-722. [CrossRef]

56. Alsayegh, G.; Mukhopadhyaya, P.; Wang, J.; Zalok, E.; van Reenen, D. Preliminary characterization of physical properties of cross-laminated-timber (CLT) panels for hygrothermal modelling. Adv. Civ. Eng. Mater. 2013, 2, 20120048. [CrossRef]

57. Yoo, J.; Chang, S.J.; Lee, J.; Wi, S.; Kim, S. Numerical analysis of hygrothermal properties and behavior of Korean based cross-laminated timber (CLT) wall system to deduce optimal assemblies. J. Clean. Prod. 2019, 213, 1217-1227. [CrossRef]

58. Wang, L.; Ge, H. Hygrothermal performance of cross-laminated timber wall assemblies: A stochastic approach. Build. Environ. 2016, 97, 11-25. [CrossRef]

59. Dong, Q.; Xing, K.; Zhang, H. Artificial neural network for assessment of energy consumption and cost for cross laminated timber office building in severe cold regions. Sustainability 2017, 10, 84. [CrossRef]

60. Guo, H.; Liu, Y.; Meng, Y.; Huang, H.; Sun, C.; Shao, Y. A comparison of the energy saving and carbon reduction performance between reinforced concrete and cross-laminated timber structures in residential buildings in the severe cold region of China. Sustainability 2017, 9, 1426. [CrossRef]

61. Maroušek, J.; Strunecký, O.; Stehel, V. Biochar farming: Defining economically perspective applications. Clean Technol. Environ. Policy 2019, 21, 1389-1395. [CrossRef]

62. Maroušková, A.; Braun, P. Analysis of Czech Subsidies for Solid Biofuels. Int. J. Green Energy 2014, 12, 405-408.

63. Khavari, A.M.; Pei, S.; Tabares-Velasco, P.C. Energy consumption analysis of multistory cross-laminated timber residential buildings: A comparative study. J. Arch. Eng. 2016, 22, 04016002. [CrossRef]

64. Jowett, $\mathrm{O}$. The thermal behaviour of cross-laminated timber construction and its resilience to summertime overheating. In Proceedings of the PLEA 2011-the 27th Conference on Passive and Low Energy Architecture, Louvain-la-Neuve, Belgium, 13-15 July 2011; pp. 339-344.

65. Adekunle, T.O. Thermal comfort and heat stress in cross-laminated timber (CLT) school buildings during occupied and unoccupied periods in Summer. In Proceedings of the 10th Windsor Conference, London, UK, 12-15 April 2018; pp. 12-15.

66. Adekunle, T.O.; Nikolopoulou, M. Thermal comfort, summertime temperatures and overheating in prefabricated timber housing. Build. Environ. 2016, 103, 21-35. [CrossRef]

67. Wyss, S.; Fazio, P.; Rao, J.; Kayello, A. Investigation of Thermal Performance of Structural Insulated Panels for Northern Canada. J. Arch. Eng. 2015, 21, 04015006. [CrossRef]

68. Vala, J. Computational identification of thermal technical properties of building materials and its reliability. AIP Conf. Proc. 2010, 1281, 2009-2012.

69. Zach, J.; Korjenic, A.; Petránek, V.; Hroudová, J.; Bednar, T. Performance evaluation and research of alternative thermal insulations based on sheep wool. Energy Build. 2012, 49, 246-253. [CrossRef]

70. Janczarek, M.; Bulyandra, O. Computer Modelling of Energy Saving Effects. Appl. Comput. Sci. 2016, 12, $47-60$. 
71. Št'astnık, S.; Vala, J.; Kmınová, H. Identification of basic thermal technical characteristics of building materials. Kybernetika 2007, 43, 561-576.

72. Albatici, R.; Passerini, F.; Tonelli, A.M.; Gialanella, S. Assessment of the thermal emissivity value of building materials using an infrared thermovision technique emissometer. Energy Build. 2013, 66, 33-40. [CrossRef] 